\title{
IMPACT OF THE GOVERNOR'S REGULATION NO. 79 THE YEAR 2020 AS EFFORT TO PREVENT AND CONTROL CORONA VIRUS DISEASE 2019 IN EAST JAKARTA ADMINISTRATIVE CITY
}

\author{
Yasef FIRMANSYAH \\ Public Administration Study Program FISIP University Prof. Dr. Moestopo (Beragama) \\ yasef@dsn.moestopo.ac.id
}

\begin{abstract}
WHO declared the COVID-19 outbreak in China an international public health emergency posing a high risk to countries with vulnerable health systems and on March 11, 2020 WHO declared the COVID-19 outbreak a pandemic. The COVID-19 pandemic very quickly spread to various parts of the world and in the initial period of its spread, the COVID-19 pandemic has spread to more than 215 countries. In accordance with the guidelines by the WHO, the provincial government of DKI Jakarta makes policies contained in the Governor's Regulation no. 79 of 2020 concerning the Implementation of Discipline and Law Enforcement of Health Protocols as an Effort and Control of COVID-19 which regulates the obligation to use masks when doing activities outside the home. This action was taken by the government considering that splashes from the respiratory tract are the most likely route for the spread of COVID-19, therefore in addition to washing hands and maintaining cleanliness, the use of masks is also very important to break the chain of spread of COVID- 19 . Impact of Governor Regulation No. 79 of 2020 concerning the Implementation of Discipline and Law Enforcement of Health Protocols as an Effort and Control of COVID-19, technically, every day there is increasing public awareness of the importance of using masks. Crowded places such as markets, restaurants, nightclubs, are locations in East Jakarta that still need a lot of monitoring even though the number of violations is felt to be decreasing day by day, but vigilance and self-awareness of the importance of using masks still need to be instilled.
\end{abstract}

Keywords: Impact, Public Policy, Governor Regulation, COVID-19

\section{BACKGROUND}

As of December 31, 2019, 27 cases of pneumonia of unknown etiology were identified in Wuhan City, Hubei province in China. The causative source was identified from a throat swab sample conducted by the Chinese Center for Disease Control and Prevention (CCDC) on January 7, 2020, and named Severe Acute Respiratory Syndrome Coronavirus 2 (SARS-CoV-2) which was later named COVID-19 by the Organization World Health Organization (WHO). WHO declared the COVID-19 outbreak in China an international public health emergency posing a high risk to countries with vulnerable health systems and on March 11, 2020, WHO declared the COVID-19 outbreak a pandemic. The COVID-19 pandemic very quickly spread to various parts of the world and in the initial period of its spread, the COVID-19 pandemic had spread to more than 215 countries and on March 6, 2020, the Indonesian government announced the first case of COVID-19 in Indonesia.

The SARS-CoV-2 virus spreads between people, one of which is through the respiratory droplets route, which is the most common mode of transmission produced during coughing, sneezing, and normal breathing. COVID-19 is an infectious disease that should be avoided, therefore preventive measures and breaking the chain of spread are very necessary and must be carried out. This COVID-19 pandemic not only affects the health crisis, but also has an impact on the economic crisis and social crisis, the emergence of fear and concern in the community, the delay in the continuity of human activities, and many other impacts caused by the COVID-19 pandemic. Therefore, the Government of Indonesia swiftly implements policies and regulations that are considered to be able to overcome the problem of the spread of the COVID-19 virus, one of which is by implementing preventive measures which are the most appropriate alternative to prevent the spread of COVID-19. The recommended preventive measures include washing hands, covering the mouth when coughing and talking, keeping a distance from other people, as well as monitoring and self-isolation for people suspected of being infected, and maintaining personal hygiene as one of the steps to avoid the spread of COVID-19.

One of the recommended efforts to prevent the spread of the virus is the use of masks to prevent respiratory droplets (droplets) which are the way the virus transmission occurs. The use of masks is part of a comprehensive series of prevention and control measures that can limit the spread of certain viral respiratory diseases, including COVID-19. According to the World Health Infection Prevention and Control of Epidemic and Pandemic-prone Respiratory Infections in Health Care guidelines, masks can be used either to protect healthy people (used to protect themselves when in contact with an infected person) or to be worn by an infected person to protect themselves from infection. prevent further transmission. Following the guidelines by the WHO, the provincial government of DKI Jakarta makes policies contained in the Governor's Regulation no. 79 of 2020 concerning the Implementation of Discipline and Law Enforcement of Health Protocols as an Effort and Control of COVID-19 which regulates the obligation to use masks when doing activities outside the home. This action was taken by the government considering that splashes from the respiratory tract are the most likely route for the spread of COVID-19, therefore in addition to washing hands and maintaining cleanliness, the use of masks is also very important to break the chain of the spread of COVID-19. 
However, there are still many people who think that the regulations or public policies made by the government are not important so that there are still many violations committed by the community by not wearing masks when doing activities outside the home even though sanctions have been imposed for violators of Provincial Government regulations. DKI Jakarta, which causes cases of COVID-19 transmission in DKI to continue to increase every day.

To analyze the impact of the governor's regulation no. 79 of 2020 concerning the application of discipline and law enforcement of health protocols as prevention and control efforts coronavirus disease 2019 in DKI Jakarta province, so this study will use the theory of public policy.

Pressman and Widavsky as quoted by Budi Winarno (2002:17) define public policy as a hypothesis containing initial conditions and predictable consequences. Public policy must be distinguished from other forms of policy, such as privacy policy. This is influenced by the involvement of non-government factors. Robert Eyestone as quoted by Leo Agustino (2008:6) defines public policy as "the relationship between government units and their environment". Many people think that the definition is still too broad to understand because what is meant by public policy can cover many things. According to Nugroho, there are two characteristics of public policy, namely: 1) public policy is easy to understand because its meaning is things that are done to achieve national goals; 2) public policy is easy to measure, because the measurement is clear, namely the extent to which progress has been made in achieving the goals.

According to Woll as quoted by Tangkilisan (2003:2) states that public policy is several government activities to solve problems in society, either directly or through various institutions that affect people's lives. Thomas $\mathrm{R}$ Dye as quoted by Islamy (2009: 19) defines public policy as "Is whatever government chooses to do or not to do" (whatever the government chooses to do or not to do). This definition emphasizes that public policy is about the realization of "action" and is not a mere statement of the will of the government or public officials. In addition, the government's choice not to do something is also a public policy because it has an influence (the same impact as the government's choice to do something. Several experts define public policy as an action taken by the government in response to a crisis or public problem. Likewise with Chandler and Plano as quoted by Tangkilisan (2003:1) which states that public policy is a strategic use of existing resources to solve public or government problems. Furthermore, it is said that public policy is a form of intervention carried out continuously by the government. for the benefit of disadvantaged groups in society so that they can live, and participate in broad development. David Easton as quoted by Leo Agustino (2009: 19) defines public policy as "The authoritative allocation of values for the whole society".
This definition emphasizes that only the owner of authority in the political system (government) can legally do something to the community and the government's choice to do something or not to do something is manifested in the form of the allocation of values. This is because the government is included in the "authorities in a political system" namely the rulers in the political system who are involved in the daily affairs of the political system and have responsibilities in a certain problem where at one point they are asked to make decisions in the future. accepted and binding on most members of society for a certain period. Based on the opinions of various experts, it can be concluded that public policy is a series of actions taken or not taken by the government that is oriented towards certain goals to solve public problems or in the public interest. The policy to do something is usually stated in the provisions of laws and regulations made by the government so that it has a binding and coercive nature.

\section{RESEARCH METHODOLOGY}

The type of research used in this research is descriptive analysis research type with a qualitative approach. According to Bogdan and Taylor, as quoted by Lexy J. Moleong (2010:4), qualitative research methods are defined as research procedures that produce descriptive data in the form of written or spoken words from people and observed behavior. Ronny Kountur (2007:105) in his book research methods says that descriptive research is a type of research that provides a description or description of a situation as clearly as possible without any treatment of the object under study. According to Irawan (Ali Baroroh, 2008:1), descriptive analysis is an analytical method that aims to describe or explain something as it is. This descriptive research is intended to find out the facts, symptoms, or certain phenomena descriptively.

\section{RESEARCH RESULTS AND DISCUSSION}

As the first region to receive PSBB determination, DKI Jakarta Province has developed PSBB policies into 3 (three) models. The first model is a strict PSBB, where this model imposes a temporary suspension: learning activities in schools/educational institutions, work activities at work/offices; and religious activities in places of worship; social and cultural activities that cause crowds of people; movement of people/goods. In addition, restrictions on activities in public places/facilities are also imposed; as well as the obligation for all parties to comply with health protocols.

The provisions for implementing this strict PSBB are regulated in Pergub No. 33 of 2020. In strengthening this strict PSBB, arrangements are also made for the imposition of sanctions for violations of PSBB implementation as regulated in Pergub No. 41 of 2020. The second model of implementing the PSBB in Jakarta is the Transitional PSBB. In the implementation of the PSBB, several sectors that previously had their 
activities suspended can now resume running with activity restrictions and the implementation of prokes. The provisions for implementing the Transitional PSBB are regulated in Pergub No. 51 of 2020 which was later replaced with Pergub No. 80 of 2020 and revised again through Pergub No. 84 of 2020. Meanwhile, related to the application of discipline and law enforcement, it is regulated in Pergub No. 79 the year 2020.

Governor Regulation (Pergub) Number 79 of 2020 concerning the Implementation of Discipline and Law Enforcement of Health Protocols is one of the policies taken by the DKI Jakarta provincial government as an Effort to Prevent and Control COVID-19 All provisions in this regulation apply to all individuals along with additional rules for perpetrators businesses and managers of public spaces, including offices, tourist attractions, hotels, industries, educational institutions, places of worship, public transportation, restaurants, cafes, street vendors, clinics, etc. Business Actors and Managers of Public Facilities are required to limit the number of people in the room to a maximum of only 50 percent of the maximum capacity. The people inside must be in good health, clean, and wearing masks. Body temperature checks, hand sanitizers, hand washing stations, as well as cleaners or disinfectants must be available in the room. For those who are required to undergo self-isolation, business owners/ companies are prohibited from dismissing them. For those who violate the above rules for the first time, the Satpol PP, the police, or the army have the right to force shut down for three consecutive days. Masks are mandatory items outside the home, when interacting with other people, or riding a motorized vehicle. If they do not comply, the Satpol PP, the police, or the army can impose a fine of Rp. 250,000 or social work sanctions in the form of cleaning public facilities for one hour. Pictures of positive cases of COVID-19 in DKI Jakarta in figure 1.
If you look at the data on the positive number of COVID 19, which continues to grow every day, it can be said that DKI Jakarta provincial policies have not been successful, but this is not the only benchmark for the still increasing number of positive COVID 19. This policy should even be appreciated considering that It is not easy to bring order to Jakarta residents who are part of a heterogeneous society from various regions, ethnicities, and groups. Without a high awareness of the policies of the DKI Jakarta provincial government in terms of preventing and controlling COVID 19, it is difficult to succeed. The level of community compliance is still lacking seen from the high violations that occur, one of which is a very simple violation, for example, the use of individual masks, there are still many people in the East Jakarta administration city who are disobedient and disciplined. This policy was made as to the legal basis for the application of discipline and law enforcement related to the health protocol. In East Jakarta, this has been effectively done as an effort to apply discipline. The following table shows the performance of the East Jakarta City Administration Satpol PP to apply the discipline of the health protocol for the use of masks.

Based on the results of interviews conducted with the East Jakarta Civil Service Police Unit regarding the discipline of using masks in the people of DKI Jakarta, every day there is increasing public awareness of the importance of using masks amid the current COVID-19 pandemic. However, there are still many people in the East Jakarta Administration City whose use is still negligent by not paying attention to proper and correct use, namely covering the nose to the chin. Crowded places such as markets, restaurants, nightclubs, are locations in East Jakarta that still need a lot of monitoring even though the number of violations is felt to be decreasing day by day, but vigilance and self-awareness of the importance of using masks still need to be instilled.

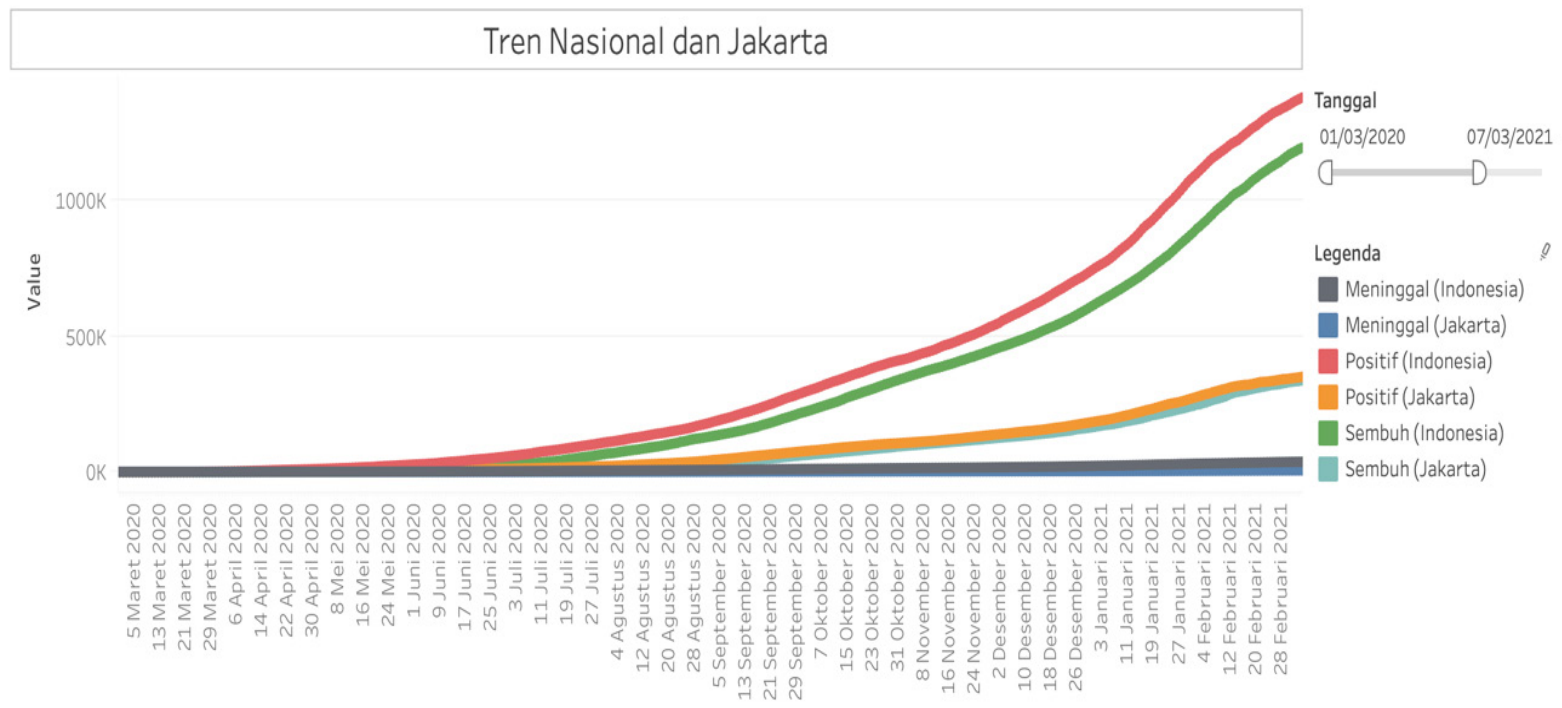

Figure 1. the Accumulative Table of Positive Data for Positive Cases of COVID-19 in DKI Jakarta

Source: DKI Jakarta Provincial Health Office which has been reported to the Indonesian Ministry of Health for February 2021 (https://corona. jakarta.go.id/id/data-monitoring) 
Table 1. of Individual Fines for Violations of Using Individual Masks Governor Regulation No.79 of 2020 East Jakarta Administrative City

\begin{tabular}{clcccc}
\hline N0. & Implementing & Social work & Fines & Nominal & Amount of Fines \\
\hline 1 & TINGKAT KOTA & 2182 & 92 & 2274 & Rp16,800,000 \\
2 & MATRAMAN & 3898 & 54 & 3952 & Rp11,350,000 \\
3 & PULO GADUNG & 5430 & 134 & 5564 & Rp18,830,000 \\
4 & JATINEGARA & 2640 & 81 & 2721 & Rp17,600,000 \\
5 & KRAMAT JATI & 7524 & 251 & 7775 & Rp58,850,000 \\
6 & PASAR REBO & 4606 & 22 & 4628 & Rp5,250,000 \\
7 & CAKUNG & 3933 & 98 & 4031 & Rp22,910,000 \\
8 & DUREN SAWIT & 4709 & 63 & 4772 & Rp15,200,000 \\
9 & CIRACAS & 5971 & 184 & 6155 & Rp40,100,000 \\
10 & MAKASAR & 3140 & 224 & 3364 & Rp30,750,000 \\
11 & CIPAYUNG & 5464 & 93 & 5557 & Rp16,050,000 \\
& JUMLAH & $\mathbf{4 9 4 9 7}$ & $\mathbf{1 2 9 6}$ & $\mathbf{5 0 7 9 3}$ & Rp253,690,000 \\
\hline
\end{tabular}

The DKI Jakarta Provincial Government in implementing the policy implementation has utilized all available resources. Technically, the DKI Provincial Government has made efforts by dividing and placing officers at various points throughout Jakarta, in shopping centers, traditional markets, on the Jakarta border in collaboration with law enforcement officers of the TNI and POLRI. In addition, officers also carry out patrols around the area. The authority of officers in implementing policies is limited because Governor Regulation no. 79 of 2020 concerning the Implementation of Discipline and Law Enforcement of Health Protocols as an Effort and Control of COVID-19 does not contain explicit authority and criminal sanctions. In the exercise of the officer's authority, it is only to discipline and give administrative and social sanctions.

Public policy is made as an action taken by the government in response to a crisis or public problem. Public policy is the strategic use of existing resources to solve public or government problems which can also be done through continuous intervention by the government for the benefit of disadvantaged groups in society so that they can live in this case. intended for groups of people who are vulnerable to contracting COVID 19. The owner of authority in the political system (government) who can legally do something to the community and the government's choice to do something or not do something is manifested in the form of the allocation of values. This is because the government is included in the "authorities in a political system" namely the rulers in the political system who are involved in the daily affairs of the political system and have responsibilities in a certain problem where at one point they are asked to make decisions in the future. accepted and binding on most members of society for a certain period. The policy to do something is usually stated in the provisions of laws and regulations made by the government so that it has a binding and coercive nature.

\section{CONCLUSION}

To support the policy, the DKI Jakarta Provincial Government has empowered existing resources such as human resources to appeal and apply regulations so that people stay at home. The DKI Jakarta government from all levels has carried out coordination and communication with the central government, police institutions, TNI, law enforcers with the intention that all these components can support each other, complement each other, complement each other to maximally apply discipline in the context of preventing and controlling the spread of COVID 19 in the community.

The readiness of the DKI Jakarta Government in implementing policies so far has gone well, the positive impact of the Satpol PP performance in applying discipline every day is increasing public awareness of the importance of using masks amid the COVID-19 pandemic as it is today. In addition, the DKI Jakarta government has not explicitly stated the authority and criminal sanctions. In the implementation of enforcement of regulations, the authority of officers is only to discipline, urge and give administrative sanctions and social sanctions for people who violate them so that it is also seen as conducive and does not cause other social problems from the impact of enforcing governor's regulation no. 79 of 2020 concerning the Implementation of Discipline and Law Enforcement of Health Protocols as Efforts and Control of COVID-19. The consistency of the DKI Jakarta Provincial Government in implementation can be seen through the Satpol PP as technical implementers who have divided and placed officers at various points throughout Jakarta, in shopping centers, on the Jakarta border in collaboration with law enforcement officers of the TNI and Polri. In addition, officers also routinely carry out mobile patrols, therefore the level of community compliance is still felt to be lacking and the use of masks is good and correct, namely covering the nose to the chin which needs to be educated. 


\section{REFERENCES}

Agustino, Leo. 2008. Dasar-Dasar Kebijakan Publik, Bandung: Alfabeta

Baroroh, Ali. (2008). Trik Trik Analisis Statistik dengan SPSS 15. Jakarta: PT Elex Media Komputindo, Kelompok Gramedia.

Hesel Nogi S.Tangkilisan, 2003. Implementasi Kebijakan Publik: Transformasi Pemikiran, Yogyakarta:Y.A.P

Islamy, M. Irfan, MPA, 1986, Prinsip-Prinsip Perumusan Kebijaksanaan Negara FIA. Unibraw, Jakarta: PT. Bina Aksara.

Kountur, Ronny. 2007. Metode Penelitian untuk penulisan Skripsi dan Tesis, edisi revisi. Jakarta: penerbit PPM.

Moleong, Lexi J. 2010. Metodelogi Penelitian Kualitatif. Bandung: PT. Rosdakarya

Nugroho, Riant. 2003. Kebijakan Publik: Perumusan, Implementasi, Evaluasi, Jakarta: PT. Elex Media Komputindo

Winarno, Budi. 2012. Kebijakan Publik: Teori, Proses, dan Studi Kasus. Yogyakarta: CAPS.

Indonesia Public Health Association. (2020). Early warning of the Coronavirus. Jakarta: Indonesia Public Health Association
Liu, Christopher, et al. "Universal public mask wear during COVID-19 pandemic: Rationale, design and acceptability." Respirology (Carlton, Vic.) 25.8 (2020): 895.

Putri, S. I. Studi Literatur: Efektivitas Penggunaan Masker Kain dalam Pencegahan Transmisi COVID-19.

Revida, E., Hidayatulloh, A. N., Soetijono, I. K., Hermawansyah, A., Purba, B., Tawakkal, M. I., ... \& Asmarianti, A. (2020). Teori Administrasi Publik. Yayasan Kita Menulis.

Sohrabi, Catrin, et al. "World Health Organization declares global emergency: A review of the 2019 novel coronavirus (COVID-19)." International Journal of Surgery (2020).

Wiersinga, W. Joost, et al. "Pathophysiology, transmission, diagnosis, and treatment of coronavirus disease 2019 (COVID-19): a review.” Jama 324.8 (2020): $782-793$

Corona.jakarta.go.id, Jakarta Smart City, Dinas Kesehatan Provinsi DKI Jakarta, Jakarta Satu (https:// jakartasatu.jakarta.go.id) 